\title{
Subcontracting Structure and Productivity in the Japanese Software Industry
}

Kazunori MINETAKI ${ }^{1)}$ and Kazuyuki MOTOHASHI ${ }^{2)}$

1) The Research Institute for Socionetwork Strategies, Kansai University 3-3-35 Yamate-cho, Suita, Osaka 564-8680, Japan

2) School of Engineering, The University of Tokyo

7-3-1 Hongo, Bunkyo-ku, Tokyo 113-0033, Japan minetaki@rcss.kansai-u.ac.jp motohashi@tmi.t.u-tokyo.ac.jp

http://www.rcss.kansai-u.ac.jp/minetaki/ http//www.mo.t.u-tokyo.ac.jp/

Received: 9 March 2009 / Accepted: 28 July 2009

(c) Springer 2009

\begin{abstract}
This paper presents an empirical analysis of the factors determining the productivity of the software industry in Japan, using individual data from the Survey of the State of the Information Service Industry conducted in August 2006 by IPA (Information-Technology Promotion Agency, Japan). This paper focuses on the relationship between the subcontracting structure and productivity in the Japanese software industry. Software enterprises are classified as prime contractors, intermediate subcontractors, end-contractors, and independent enterprise. A comparison of their productivity levels reveals that intermediate subcontractors are the least productive. However, it is observed that the intermediate subcontractors possessing a high quality of human resources measured the proportion of employees passing the Information Technology Engineers Examination (ITEE), or the intermediate subcontractors adopting the IT skill standard which defines the skills for IT human resources clearly and systematically, has a high productivity level. It can raise the productivity in software industry as a whole.
\end{abstract}

Keywords: Software, Subcontracting structure, Productivity, Information Technology Engineers Examination (ITEE), IT skill standard.

\section{Introduction}

In order to boost the potential growth rate of the Japanese economy, the productivity of the service industry must be increased. In its current state, the rate that productivity is increasing in Japan's service industry is low considering international trends, despite the high importance of the service industry. The service industry accounts for a high share of both GDP and of employment in comparison to the manufacturing 
industry. The trend of moving towards a service economy is not limited to Japan, and is also occurring in each of the OECD countries. The share which is $45-55 \%$ of GDP occupied by the service market in 2001 had increased by $10 \%$ with respect to 1980 in the OECD countries.

The service industry does not only have a high share, it is also important from the perspective of innovation. The service industry includes many knowledge-based fields such as healthcare, education and consulting. Software enterprises are an archetypical example of knowledge-based service enterprises with a high potential for productivity increase through innovation. The demand for software is increasing dramatically due to the advance of IT throughout the economy as a whole, and there are high expectations that the software industry, with its increasing productivity supported by advances in software engineering and an accumulation of software development tools, will draw up the productivity of the Japanese economy at a macroscopic level.

However, when the speed of innovation in the software industry is compared with that of the IT hardware industry, it is lagging behind. Hardware for computers and communications devices are supported by Moore's law of semiconductor integrated circuits, and technological innovation is advancing at a remarkable speed. For software on the other hand, despite the fact that development environments are improving through development tools such as CASE (Computer Aided Software Engineering) and the appearance of programming languages, which are closer to natural languages, productivity is strongly colored by a labor-intensive aspect that hinges upon the abilities of software programmers. It is therefore thought that the growth in productivity is slack in comparison to the remarkable advance of production technologies in IT hardware.

The competitive standing of the software industry in Japan is notably low in terms of trade statistics, and its productivity is considered low in comparison to that of Europe and the United States (Imai and Ishino [1]). It is thought that this may be caused by a low ratio of package software for which the merit of scale begins to function and a high proportion of software orders which necessitate responses to individual clients (Tanaka [2], Motohashi [3]). It is also thought that the fact that many of the software enterprises are medium- to small- sized enterprises with a low productivity, and the multi-tiered market structure composed of large enterprises acting as prime contractors and enterprises acting as end-contractors bear an influence.

This paper presents an empirical analysis of the productivity of the software industry in Japan and its market structure using individual data from the Survey of the State of the Information Service Industry conducted by IPA (Information-Technology Promotion Agency, Japan). Productivity was compared with respect to the types of software enterprises in the multi-tiered trade structure of prime contractors and subcontractors, and the causes of the low productivity of the software industry itself were investigated. The quality of human resources is also an important factor in software productivity, and an analysis of its relationship to productivity was also conducted.

The remainder of this paper is organized as follows. First, Section 2 summarizes the previous related literatures. In Section 3, the data used in this research is described, and enterprises are classified by type according to the trade patterns in the 
software industry, and descriptive statistics are presented. In Section 4, the framework for productivity analysis is presented and estimation results are reported. Section 5 concludes.

\section{Previous Literature}

We summarize the previous studies related with the quantitative analysis in the Japanese software industry.

There are several databases concerning about the software industry. The Survey of Selected Services Industries of which the business categories are software and information service by METI (Ministry of Economy, Trade, and Industry), and Survey of the State of the Information Service Industry by IPA are famous. But those databases include software industry and also information service industry. There are many enterprises which have both the software sector and the other information service sector including internet and information processing, so both industries are generally researched together. For estimation, most previous studies control the difference between the software sector and the other information service sector.

Shintani [4], Nishimura and Minetaki [5], and Minetaki and Motohashi [6] conduct the empirical studies by using the database of 'The Survey of Selected Services Industries'.

Shintani [4] analyzes the labor productivity of the software and information service enterprises each year 1983-1996 separately by using CES (Constant Elasticity of Substitution) type production function which uses the number of system engineer to total employees, the number of programmer to total employees, and the number of researcher to total employees to represent the quality of labor. Main result is that the number of system engineer to total employees has the stronger tendency to bring the positive effect on the technological progress compared with types of labor.

Nishimura and Minetaki [5] analyzes TFP (Total Factor Productivity) of the software and information service enterprises by using panel data from 1991-1998. It shows that because the outsourcing of developing software is not efficiently operated, the information service industry has run into an exacerbated state of low productivity. And according to Nishimura and Minetaki [5], the number of system engineer to total employees has the positive effect on TFP.

Minetaki and Motohashi [6] ${ }^{1}$ analyzes TFP of the software enterprises mainly ${ }^{2}$ by using panel data from 2000 to 2005. Minetaki and Motohashi [6] classifies software enterprises as prime contractors, intermediate subcontractors, end-contractors, and independent enterprise by using the measurement of outsourcing expense ratio and

\footnotetext{
${ }^{1}$ This paper uses the cross sectional data of Survey of the State of the Information Service Industry IPA. On the other hand, Minetaki and Motohashi [6] uses the panel data of Survey of Selected Services Industries of which the business categories are software and information service by METI.

${ }^{2}$ Minetaki and Motohashi [6] targets the enterprises of which software business share of sales is higher over $80 \%$.
} 
intra-industry sales ratio. The particularity of Minetaki and Motohashi [6] is to investigate the relationship between TFP and patent or R\&D investment in each classified software enterprises. Also Minetaki and Motohashi [6] investigates the relationship between TFP and the labor quality measured by the type of labor which are the number of system engineer to total employee and the number of programmer to total employee. As the empirical study results, Minetaki and Motohashi [6] concludes that for the prime contractors, the innovative activity of patent and R\&D investment is the most important, and for the independent enterprise, the quality of labor is the most important to determine TFP.

Hiromatsu, et al. [7] develops their original database ${ }^{3}$ from 1994 to 2003. Hiromatsu, et al. [7] clarifies the source of competitive edge of information services enterprise by empirical analyses of that those management resources effect on value added from the viewpoint of sale economy by using translog type cost function and SEM (Structural Equation Modeling). Hiromatsu, et al. [7] concludes that business model, human resources which have rich talents and technology measured by the proportion of employees qualified with the advanced IT certification and the ratio of researcher to total employees, and outsourcing are closely related to scale economies, and the most important management resource.

This paper investigates the relationship between the subcontracting structure and productivity as same as Minetaki and Motohashi [6] because we think the subcontracting structure is the particularity in the Japanese software industry. We use the ratio of outsourcing cost to total cost when classifying software enterprises, and therefore our study is related to Nishimura and Minetaki [5] and Hiromatsu, et al. [7].

Also we share the view that the labor qualities have the effect on the productivity, with Shintani [4], Nishimura and Minetaki [5], and Hiromatsu, et al. [7].

\section{Overview of the Data and Classification of Software Enterprises}

In this section, we overview our data set and we classifies the software enterprises. The purpose of using Survey of the State of the Information Service Industry is that we can study empirically the relationship between the IT skill which employees hold and the productivity in the Japanese software industry. ${ }^{4}$

In order to grasp the state of trade in software enterprises, Survey of the State of the Information Service Industry is conducted every year. The research described in this paper used the enterprise data from the '28 ${ }^{\text {th }}$ Survey' conducted in August 2006. This survey targets the information service industry including custom software, prepackaged software, internet related field, information processing and other information services. The items in this survey includes are financial accounts and

\footnotetext{
${ }^{3}$ Hiromatsu,et al. [7] integrates the financial database of each enterprise and 'information service enterprise register'.

${ }^{4}$ Because the data of using in this paper is the cross sectional data, we can not strictly treat the causal relationship and so we investigate the correlation in this paper.
} 
revenue statement, state of loans, employment, The Information Technology Engineers Examination and the IT skill standards. For the enterprise targeted by the survey, 861 businesses provided valid responses (581 software businesses, and 280 businesses providing IT services), and the ratio of valid respondents was $21.5 \%$.

We classify the enterprises into four enterprise groups according to two indicators of the outsourcing cost ratio (the proportion of total cost occupied by outsourcing cost), and the intra-industry sales ratio (the proportion of sales which contribute to the sales within the information service industry as a whole). ${ }^{5}$ Enterprises were identified as having above or below average outsourcing cost ratios and intra-industry sales ratios, and classified into the four groups shown in Table 1.

Enterprises with a high outsourcing cost ratio and a low intra-industry sales ratio were considered to be large enterprise prime contractors. Large enterprise prime contractors are located at the top of the pyramidal structure of industrial organizations, because they tend to have a high proportion of sales outside the software industry, while themselves largely outsourcing to subcontractors.

Enterprises with a high outsourcing cost ratio and a high intra-industry sales ratio are considered to be intermediate subcontractors. It was thought that they tend to receive orders from prime contractors while themselves subcontracting.

Enterprises with a low outsourcing cost ratio and a high intra-industry sales ratio are considered to be end-contractors, because their low outsourcing cost ratio indicates that they do not place orders with enterprises beneath them, while their high intra-industry sales ratio indicates that their sales are largely for intermediate subcontractors.

Table 1. Classification of enterprises in software industry

\begin{tabular}{|l|l|l|}
\hline & $\begin{array}{l}\text { Above average } \\
\text { intra-industry sales ratio }\end{array}$ & $\begin{array}{l}\text { Below average } \\
\text { intra-industry sales ratio }\end{array}$ \\
\hline $\begin{array}{l}\text { Above average outsourcing } \\
\text { cost ratio }\end{array}$ & intermediate subcontractors & prime contractors \\
\hline $\begin{array}{l}\text { Below average outsourcing } \\
\text { cost ratio }\end{array}$ & end-contractors & independent enterprises \\
\hline
\end{tabular}

${ }^{5}$ Our classification of the enterprises was verified by the $29^{\text {th }}$ Survey of the State of the Information Service Industry conducted in 2007 by IPA. 
Table 2. Descriptive statistics

\begin{tabular}{|c|c|c|c|c|c|}
\hline & Total & $\begin{array}{c}\text { prime } \\
\text { contractors }\end{array}$ & $\begin{array}{c}\text { intermediate } \\
\text { subcontractors }\end{array}$ & end-contractors & $\begin{array}{c}\text { independent } \\
\text { enterprises }\end{array}$ \\
\hline Value Added & 2698 & 5347 & 1710 & 1297 & 1893 \\
\hline Physical fixed assets & 621 & 1178 & 316 & 342 & 528 \\
\hline Software assets & 327 & 610 & 91 & 51 & 416 \\
\hline Number of employees & 273 & 477 & 219 & 173 & 187 \\
\hline Labor productivity & 4248 & 4944 & 3380 & 4221 & 4387 \\
\hline Outsourcing cost ratio & 0.23 & 0.33 & 0.36 & 0.10 & 0.08 \\
\hline Intra-industry sales ratio & 0.28 & 0.04 & 0.66 & 0.58 & 0.04 \\
\hline Custom Software sales ratio & 0.54 & 0.55 & 0.76 & 0.56 & 0.33 \\
\hline Software product sales ratio & 0.09 & 0.04 & 0.04 & 0.15 & 0.16 \\
\hline Software sales ratio & 0.63 & 0.59 & 0.80 & 0.71 & 0.49 \\
\hline $\begin{array}{l}\text { Employees passing the } \\
\text { Information Technology } \\
\text { Engineers Examination ratio }\end{array}$ & 0.38 & 0.44 & 0.42 & 0.29 & 0.34 \\
\hline $\begin{array}{l}\text { Ratio of enterprises } \\
\text { adopting the IT skill } \\
\text { standard }\end{array}$ & 0.13 & 0.21 & 0.16 & 0.04 & 0.08 \\
\hline $\begin{array}{l}\text { Number of enterprises } \\
\text { which have Partnerships } \\
\text { with computer maker }\end{array}$ & 45 & 23 & 23 & 4 & 10 \\
\hline $\begin{array}{l}\text { Number of enterprises } \\
\text { which have Partnerships } \\
\text { with computer user }\end{array}$ & 85 & 37 & 23 & 5 & 34 \\
\hline Number of enterprises & 439 & 120 & 116 & 67 & 136 \\
\hline
\end{tabular}

(Note) Value Added, Physical fixed assets, and Software assets are shown at 100 million yen respectively. Labor productivity is shown at yen per man hour.

Last, enterprises with both a low outsourcing cost ratio and a low intra-industry sales ratio are considered to be independent enterprises with no dependence on enterprises in the same industry.

Table 2 summarizes the characteristics of each of the groups in this classification of software enterprises, showing their value added, physical fixed assets, software assets, number of employees, labor productivity ${ }^{6}$, outsourcing cost ratio (the proportion of total cost occupied by outsourcing cost), intra-industry sales ratio (the proportion of total sales which contribute to the sales of the IT service industry), custom software sales ratio (custom software sales to total sales), software product sales ratio (software product sales to total sales), and employees passing the Information Technology Engineers Examination (ITEE) to total employee.

Insofar as can be seen from descriptive basic statistics, one result is that the labor productivity of the prime contractor group is the highest. The value added, physical fixed assets and number of employees are also overwhelmingly high for this group of enterprises. Next, in the independent enterprises the labor productivity is relatively high.

The custom software sales ratio is the highest for the intermediate subcontractor group. The pyramidal structure of industrial organizations is a phenomenon often

${ }^{6}$ This is obtained by dividing the value added by the labor input (number of employees multiplied working time). 
observed with custom software. In particular, the ratio of custom software sales is the highest for the enterprises in the intermediate subcontractor group. Subcontracting downstream is a characteristic of software development in Japan, particularly for custom software.

The proxy for the labor quality is the ratio of employees passing ITEE which is a national examination under METI. The ratio of employees passing the ITEE to total employees is comparatively higher for the enterprises in the prime contractor group and in the intermediate subcontractor group.

Also proxy for the labor quality is the ratio of enterprises adopting the IT skill standard. It defines the skills for IT human resources clearly and systematically. This ratio is the highest for the enterprises in the prime contractor group.

\section{Framework for Productivity Analysis and Analytical Results}

\subsection{Analytical framework}

To obtain the robust estimation result, we use both the Cobb-Douglas production function and TFP, as the framework for analyzing the productivity of software enterprises.

In the case of the Cobb-Douglas production function, the dependant variable is the labor productivity which is the amount of value added per man hour.

Explanatory variables are, first, the capital labor ratio (the amount of capital stock per man hour). We have two types of the capital labor ratio for physical fixed assets and for software assets. Secondly, the labor quality is explanatory variable. We use the ratio of employees passing ITEE to total employees for the proxy for the labor quality. Thirdly, we use the dummy variables for business partnership with computer maker and with computer user. Fourthly, we use the ratio of software sales to control the difference between the software sector and the other information service sector. The specific formulation is as follows.

$$
\begin{aligned}
\ln \left(\frac{Y_{i}}{L_{i}}\right) & =\alpha \ln \left(\frac{K_{1, i}}{L_{i}}\right)+\beta \ln \left(\frac{K_{2, i}}{L_{i}}\right)+\lambda \times \text { labor_quality }_{i} \\
& +\sum \theta \times \text { dummy_for_partnership }_{i}+\delta \times \text { ratio_software }_{i}+\text { cons. }+\varepsilon_{i} \cdot(1)
\end{aligned}
$$

In equation (1), the variables are defined as follows:

$Y_{i}=$ Value added of the $i^{\text {th }}$ enterprise,

$K_{1, i}=$ Capital stock (physical fixed assets) of the $i^{\text {th }}$ enterprise,

$K_{2, i}=$ Capital stock (software assets) of the $i^{\text {th }}$ enterprise,

$L_{i}=$ Labor input (number of employees multiplied working) of the $i^{\text {th }}$ enterprise,

Labor_quality ${ }_{i}=$ Variable representing human capital, 
dummy _ for $\_$partnership $_{i}=$ Dummy variables for partnerships with computer maker or computer user ${ }^{7}$, ratio_software $e_{i}=$ Ratio of software sales to total sales, $\varepsilon_{i}=$ error term.

The assumption of Cobb-Douglas production function that the marginal substitution of inputs is 1 is strict, and so we try to use TFP where the contributions of inputs of capital stocks and labor are controlled.

$\ln \left(\frac{\mathrm{TFP}_{i}}{\overline{T F P}}\right)=\ln \left(\frac{Y_{i}}{\bar{Y}}\right)-\sum_{j=K_{1}, K_{2}, L} \frac{1}{2}\left(s_{i j}+\overline{s_{j}}\right) \ln \left(\frac{X_{i j}}{\overline{X_{j}}}\right)$.

In equation (2), the variables are defined as follows:

$T F P_{i}=$ TFP level of the $i^{\text {th }}$ enterprise,

$\overline{T F P}_{i}=$ TFP level of the average enterprise, $Y_{i}=$ Value added of the $i^{\text {th }}$ enterprise,

$\overline{Y_{i}}=$ Value added of the average enterprise,

$s_{i j}=$ Cost share of the $j^{\text {th }}$ input of the $i^{\text {th }}$ enterprise,

$\overline{s_{i j}}=$ Cost share of the $j^{\text {th }}$ input of the average enterprise,

$X_{i j}=$ The $j^{\text {th }}$ input of the $i^{\text {th }}$ enterprise,

$\overline{X_{j}}=$ The $j^{\text {th }}$ input of the average enterprise.

We define TFP level by using equation (2), and estimate TFP level as follow as equation (3).

$$
\begin{aligned}
& \ln \left(\mathrm{TFP}_{i}\right)=\lambda \times \text { labor_quality }_{i}
\end{aligned}
$$

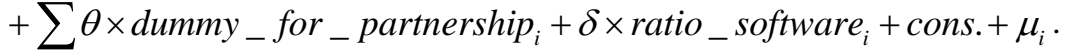

The notations of variables are the same as equations (1), (2), and $\mu_{i}$ is the error term.

The estimation method is basically OLS, but we perform the Breusch-Pagan test for heteroskedasticity. In the case that Breusch-Pagan test shows the heteroskedasticity, we use the Huber-White-sandwich estimator of variance.

${ }^{7}$ Dummy for partnerships with computer maker is 1 if the $i$ software company belong to the computer maker, otherwise 0 . Dummy for partnerships with computer user is 1 if the $i$ software company belong to the computer user, otherwise 0 . 


\subsection{Estimation results}

The estimation results are shown in Tables 3-6. Tables 3 and 4 are the results of using the ratio of employees passing ITEE where we estimate equation (1) of CobbDouglas production function in Table 3 , and we estimate equation (3) of TFP in Table 4. Also Tables 5 and 6 are the results of using the IT skill standard where we estimate equation (1) of Cobb-Douglas production function in Table 5, and we estimate equation (3) of TFP in Table 6.

There are five cases of results in each table. First is the total case. Second is the case of prime contractors. Third is the case of intermediate subcontractors. Fourth is the case of end-contractors. Fifth is the case of independent enterprises.

We mainly focus on the significance of labor quality measured by the ratio of employees passing the Information Technology Engineers Examination (ITEE) in Tables 3 and 4. The labor quality is not significant statistically in the total case. Within the classification of enterprises, the only case of intermediate subcontractors can show the positive correlation between the labor quality and productivity which is statistically significant at $1 \%$ level in the case of using Cobb-Douglas production function shown in Table 3, and also is statistically significant at $5 \%$ level in the case of using TFP shown in Table 4.

Next, we use the ratio of enterprises adopting the IT skill standard which is another proxy for labor quality. The estimation results are shown in Tables 5 and 6.

The labor quality has the positive correlation with the productivity in the case of intermediate subcontractors. Table 5 shows the results of Cobb-Douglas production function which is $5 \%$ level significant, and Table 6 shows the results of TFP which is $10 \%$ level significant. Other cases except for intermediate subcontractors are not significant statistically.

Our estimation results are concluded that the labor quality which is measured by both the ratio of employees passing ITEE and the ratio of enterprises adopting the IT skill standard, can have the correlation with the productivity in intermediate subcontractors of the software industry. 
Table 3. Estimation results (case of using the ratio of employees passing ITEE) Cobb-Douglas production function

\begin{tabular}{|c|c|c|c|c|c|}
\hline & \multicolumn{2}{|c|}{ Total } & \multicolumn{3}{|c|}{ Prime contractors } \\
\hline & coefficient & S.E. & coefficient & S.E. & \\
\hline capital labor ratio(physical fixed assets) & 0.065 & $0.013 * * *$ & 0.042 & 0.028 & \\
\hline capital labor ratio(software assets) & 0.094 & $0.011 * * *$ & 0.125 & 0.018 & $* * *$ \\
\hline quality of labor & 0.083 & 0.067 & 0.101 & 0.087 & \\
\hline dummy for partnerships with computer maker & 0.197 & $0.070 * * *$ & 0.068 & 0.058 & \\
\hline dummy for partnerships with computer user & 0.209 & $0.055 * * *$ & 0.109 & 0.083 & \\
\hline software sales ratio & 0.116 & $0.065 *$ & 0.134 & 0.122 & \\
\hline constant & -4.311 & $0.129 * * *$ & -4.103 & 0.302 & $* * *$ \\
\hline number of observations & \multicolumn{2}{|c|}{439} & \multicolumn{3}{|c|}{120} \\
\hline Breusch-Pagan Test chi2 & \multicolumn{2}{|c|}{0.42} & \multicolumn{3}{|c|}{25.2} \\
\hline Prob >chi2 & \multicolumn{2}{|c|}{0.519} & \multicolumn{3}{|c|}{0.000} \\
\hline Adj. R-squared & \multicolumn{2}{|c|}{0.263} & \multicolumn{3}{|c|}{0.455} \\
\hline & \multicolumn{2}{|c|}{ Intermediate subcontractors } & \multicolumn{3}{|c|}{ End-contractors } \\
\hline & \multicolumn{2}{|c|}{$\begin{array}{ll}\text { coefficient } & \text { S.E. } \\
\end{array}$} & coefficient & \multicolumn{2}{|l|}{ S.E. } \\
\hline capital labor ratio(physical fixed assets) & 0.026 & 0.025 & 0.081 & 0.040 & $* *$ \\
\hline capital labor ratio(software assets) & 0.056 & $0.021 * * *$ & 0.072 & 0.033 & $* *$ \\
\hline quality of labor & 0.241 & $0.088 * * *$ & -0.155 & 0.215 & \\
\hline dummy for partnerships with computer maker & 0.269 & $0.059 * * *$ & 0.167 & 0.194 & \\
\hline dummy for partnerships with computer user & 0.273 & $0.106 * *$ & -0.013 & 0.163 & \\
\hline software sales ratio & 0.373 & $0.199 *$ & 0.219 & 0.227 & \\
\hline constant & -5.397 & $0.342 * * *$ & -4.329 & 0.493 & $* * *$ \\
\hline number of observations & \multicolumn{2}{|c|}{116} & \multicolumn{3}{|c|}{67} \\
\hline Breusch-Pagan Test chi2 & \multicolumn{2}{|c|}{33.23} & \multicolumn{3}{|c|}{8.28} \\
\hline Prob >chi2 & \multicolumn{2}{|c|}{0.000} & \multicolumn{3}{|c|}{0.004} \\
\hline Adj. R-squared & \multicolumn{2}{|c|}{0.245} & \multicolumn{3}{|c|}{0.277} \\
\hline
\end{tabular}

\begin{tabular}{|l|cc|}
\hline & \multicolumn{3}{|c|}{ Independent enterprises } \\
\hline & coefficient & S.E. \\
\hline capital labor ratio(physical fixed assets) & 0.102 & $0.038 * * *$ \\
capital labor ratio(software assets) & 0.077 & $0.025 * * *$ \\
quality of labor & 0.000 & 0.175 \\
dummy for partnerships with computer maker & 0.242 & 0.238 \\
dummy for partnerships with computer user & 0.257 & $0.091 * * *$ \\
software sales ratio & 0.068 & 0.170 \\
constant & -4.165 & $0.320 * * *$ \\
\hline number of observations & \multicolumn{3}{|c|}{136} \\
Breusch-Pagan Test chi2 & \multicolumn{3}{|c|}{0.001} \\
Prob >chi2 & \multicolumn{2}{|c|}{0.200} \\
Adj. R-squared & \multicolumn{3}{|c|}{} \\
\hline
\end{tabular}

(Note) $* * *, * *$, and $*$ mean $1 \%, 5 \%$, and $10 \%$ statistically significant each other. 
Table 4. Estimation results (case of using the ratio of employees passing ITEE) TFP

\begin{tabular}{|c|c|c|c|c|c|}
\hline & \multicolumn{2}{|c|}{ Total } & \multicolumn{3}{|c|}{ Prime contractors } \\
\hline & coefficient & ust S.E. & coefficient & ust S.E. & \\
\hline quality of labor & 0.094 & 0.061 & 0.075 & 0.091 & \\
\hline dummy for partnerships with computer maker & 0.293 & $0.061 * * *$ & 0.244 & 0.092 & *** \\
\hline dummy for partnerships with computer user & 0.211 & $0.059 * * *$ & 0.206 & 0.077 & *** \\
\hline software sales ratio & 0.260 & $0.078 * * *$ & 0.219 & 0.107 & ** \\
\hline constant & -0.321 & $0.070 * * *$ & -0.208 & 0.079 & *** \\
\hline number of observations & \multicolumn{2}{|c|}{439} & \multicolumn{3}{|c|}{120} \\
\hline Breusch-Pagan Test chi2 & \multirow{2}{*}{\multicolumn{2}{|c|}{$\begin{array}{l}33.21 \\
0.000\end{array}$}} & \multirow{2}{*}{\multicolumn{3}{|c|}{2.71}} \\
\hline Prob >chi2 & & & & & \\
\hline Adj. R-squared & \multicolumn{2}{|c|}{0.090} & \multicolumn{3}{|c|}{0.116} \\
\hline
\end{tabular}

\begin{tabular}{|c|c|c|c|c|}
\hline & \multicolumn{2}{|c|}{ Intermediate subcontractors } & \multicolumn{2}{|c|}{ End-contractors } \\
\hline & coefficient & Ist S.E. & coefficient & ust S.E. \\
\hline quality of labor & 0.208 & $0.097 * *$ & -0.064 & 0.266 \\
\hline dummy for partnerships with computer maker & 0.336 & $0.065 * * *$ & 0.312 & 0.268 \\
\hline dummy for partnerships with computer user & 0.311 & $0.134 * *$ & 0.070 & 0.226 \\
\hline software sales ratio & 0.529 & $0.276 *$ & 0.304 & 0.210 \\
\hline constant & -0.640 & $0.256 * *$ & -0.245 & 0.165 \\
\hline number of observations & \multicolumn{2}{|c|}{116} & \multicolumn{2}{|c|}{67} \\
\hline Breusch-Pagan Test chi2 & \multicolumn{2}{|c|}{65.13} & \multicolumn{2}{|c|}{0.01} \\
\hline Prob >chi2 & \multicolumn{2}{|c|}{0.000} & \multicolumn{2}{|c|}{0.910} \\
\hline Adj. R-squared & \multicolumn{2}{|c|}{0.170} & \multicolumn{2}{|c|}{-0.022} \\
\hline
\end{tabular}

\begin{tabular}{|c|c|c|}
\hline & \multicolumn{2}{|c|}{ Independent enterprises } \\
\hline & \multicolumn{2}{|c|}{\begin{tabular}{|l|} 
coefficient Robust S.E. \\
\end{tabular}} \\
\hline quality of labor & 0.092 & 0.159 \\
\hline dummy for partnerships with computer maker & 0.242 & 0.177 \\
\hline dummy for partnerships with computer user & 0.141 & 0.110 \\
\hline software sales ratio & 0.153 & 0.137 \\
\hline constant & -0.294 & $0.101 * * *$ \\
\hline number of observations & \multicolumn{2}{|c|}{136} \\
\hline Breusch-Pagan Test chi2 & \multicolumn{2}{|c|}{2.12} \\
\hline Prob >chi2 & \multicolumn{2}{|c|}{0.146} \\
\hline Adj. R-squared & \multicolumn{2}{|c|}{0.005} \\
\hline
\end{tabular}

(Note) $* * *, * *$, and $*$ mean $1 \%, 5 \%$, and $10 \%$ statistically significant each other. 
Table 5. Estimation results (case of using IT skill standard) Cobb-Douglas production function

\begin{tabular}{|c|c|c|c|c|c|}
\hline & \multicolumn{2}{|c|}{ Total } & \multicolumn{3}{|c|}{ Prime contractors } \\
\hline & \multicolumn{2}{|c|}{ coefficient Robust S.E. } & \multicolumn{3}{|c|}{ coefficient Robust S.E. } \\
\hline capital labor ratio(physical fixed assets) & 0.0650 & $0.0126 * * *$ & 0.042 & 0.028 & \\
\hline capital labor ratio(software assets) & 0.0931 & $0.0108 * * *$ & 0.124 & 0.017 & *** \\
\hline quality of labor & 0.0277 & 0.0611 & 0.058 & 0.082 & \\
\hline dummy for partnerships with computer maker & 0.2119 & $0.0686 * * *$ & 0.078 & 0.061 & \\
\hline dummy for partnerships with computer user & 0.2187 & $0.0543 * * *$ & 0.114 & 0.079 & \\
\hline software sales ratio & 0.1275 & $0.0648 *$ & 0.156 & 0.110 & \\
\hline constant & -4.2993 & $0.1295 * * *$ & -4.091 & 0.283 & *** \\
\hline number of observations & \multicolumn{2}{|c|}{439} & \multicolumn{3}{|c|}{120} \\
\hline Breusch-Pagan Test chi2 & \multicolumn{2}{|c|}{0.51} & \multicolumn{3}{|c|}{23.4} \\
\hline Prob $>$ chi 2 & \multicolumn{2}{|c|}{0.477} & \multicolumn{3}{|c|}{0.000} \\
\hline Adj. R-squared & \multicolumn{2}{|c|}{0.261} & \multicolumn{3}{|c|}{0.450} \\
\hline
\end{tabular}

\begin{tabular}{|c|c|c|c|c|c|}
\hline & \multicolumn{2}{|c|}{ Intermediate subcontractors } & \multicolumn{3}{|c|}{ End-contractors } \\
\hline & \multicolumn{2}{|c|}{ coefficient Robust S.E. } & \multicolumn{3}{|c|}{ coefficient Robust S.E. } \\
\hline capital labor ratio(physical fixed assets) & 0.029 & 0.024 & 0.0810 & 0.0403 & $* *$ \\
\hline capital labor ratio(software assets) & 0.058 & $0.022 * * *$ & 0.0782 & 0.0292 & *** \\
\hline quality of labor & 0.173 & $0.072 * *$ & 0.0105 & 0.1385 & \\
\hline dummy for partnerships with computer maker & 0.288 & $0.071 * * *$ & 0.1560 & 0.1824 & \\
\hline dummy for partnerships with computer user & 0.301 & $0.103 * * *$ & -0.0072 & 0.1583 & \\
\hline software sales ratio & 0.381 & $0.198 *$ & 0.1828 & 0.2199 & \\
\hline constant & -5.281 & $0.348 * * *$ & -4.2868 & 0.4811 & $* * *$ \\
\hline number of observations & \multicolumn{2}{|c|}{116} & \multicolumn{3}{|c|}{67} \\
\hline Breusch-Pagan Test chi2 & \multicolumn{2}{|c|}{32.05} & \multicolumn{3}{|c|}{8.3} \\
\hline Prob $>$ chi 2 & \multicolumn{2}{|c|}{0.000} & \multicolumn{3}{|c|}{0.004} \\
\hline Adj. R-squared & \multicolumn{2}{|c|}{0.241} & \multicolumn{3}{|c|}{0.274} \\
\hline
\end{tabular}

\begin{tabular}{|l|rc|}
\hline & \multicolumn{2}{|c|}{ Independent enterprises } \\
\hline & coefficient & Robust S.E. \\
\hline capital labor ratio(physical fixed assets) & 0.1035 & $0.0374 * * *$ \\
capital labor ratio(software assets) & 0.0751 & $0.0242 * * *$ \\
quality of labor & -0.2711 & 0.1323 \\
dummy for partnerships with computer maker & 0.2234 & 0.2343 \\
dummy for partnerships with computer user & 0.2725 & $0.0975 * * *$ \\
software sales ratio & 0.0822 & 0.1695 \\
constant & -4.1563 & $0.3274 * * *$ \\
\hline number of observations & \multicolumn{3}{|c|}{136} \\
Breusch-Pagan Test chi2 & \multicolumn{2}{|c|}{0.001} \\
Prob >chi2 & \multicolumn{2}{|c|}{0.218} \\
Adj. R-squared & \multicolumn{2}{|c|}{} \\
\hline
\end{tabular}

(Note) $* * *, * *$, and $*$ mean $1 \%, 5 \%$, and $10 \%$ statistically significant each other. 
Table 6. Estimation results (case of using IT skill standard) TFP

\begin{tabular}{|c|c|c|c|c|c|}
\hline & \multicolumn{2}{|c|}{ Total } & \multicolumn{3}{|c|}{ Prime contractors } \\
\hline & \multicolumn{2}{|c|}{ coefficient Robust S.E. } & \multicolumn{3}{|c|}{ coefficient Robust S.E. } \\
\hline quality of labor & 0.000 & 0.051 & -0.0216 & 0.0830 & \\
\hline dummy for partnerships with computer maker & 0.314 & $0.060 * * *$ & 0.2612 & 0.0911 & *** \\
\hline dummy for partnerships with computer user & 0.225 & $0.059 * * *$ & 0.2191 & 0.0771 & *** \\
\hline software sales ratio & 0.275 & $0.078 * * *$ & 0.2412 & 0.1045 & ** \\
\hline constant & -0.299 & $0.068 * * *$ & -0.1904 & 0.0770 & ** \\
\hline number of observations & \multicolumn{2}{|c|}{439} & \multicolumn{3}{|c|}{120} \\
\hline Breusch-Pagan Test chi2 & \multicolumn{2}{|c|}{30.28} & \multicolumn{3}{|c|}{1.73} \\
\hline Prob $>$ chi2 & \multicolumn{2}{|c|}{0.000} & \multicolumn{3}{|c|}{0.188} \\
\hline Adj. R-squared & \multicolumn{2}{|c|}{0.087} & \multicolumn{3}{|c|}{0.111} \\
\hline & \multicolumn{2}{|c|}{ Intermediate subcontractors } & \multicolumn{3}{|c|}{ End-contractors } \\
\hline & \multicolumn{2}{|c|}{ coefficient Robust S.E. } & \multicolumn{3}{|c|}{ coefficient Robust S.E. } \\
\hline quality of labor & 0.157 & $0.085 *$ & 0.080 & 0.294 & \\
\hline dummy for partnerships with computer maker & 0.351 & $0.064 * * *$ & 0.292 & 0.275 & \\
\hline dummy for partnerships with computer user & 0.338 & $0.127 * * *$ & 0.071 & 0.226 & \\
\hline software sales ratio & 0.536 & $0.275 *$ & 0.289 & 0.200 & \\
\hline constant & -0.586 & $0.257 * *$ & -0.256 & 0.162 & \\
\hline number of observations & \multicolumn{2}{|c|}{116} & \multicolumn{3}{|c|}{67} \\
\hline Breusch-Pagan Test chi2 & \multicolumn{2}{|c|}{67.6} & \multicolumn{3}{|c|}{0.36} \\
\hline Prob $>$ chi 2 & \multicolumn{2}{|c|}{0.000} & \multicolumn{3}{|c|}{0.551} \\
\hline Adj. R-squared & \multicolumn{2}{|c|}{0.169} & \multicolumn{3}{|c|}{-0.022} \\
\hline & \multicolumn{2}{|c|}{ Independent enterprises } & & & \\
\hline & \multicolumn{2}{|c|}{ coefficient Robust S.E. } & & & \\
\hline quality of labor & -0.250 & 0.159 & & & \\
\hline dummy for partnerships with computer maker & 0.252 & 0.169 & & & \\
\hline dummy for partnerships with computer user & 0.169 & 0.107 & & & \\
\hline software sales ratio & 0.169 & 0.136 & & & \\
\hline constant & -0.259 & $0.093 * * *$ & & & \\
\hline number of observations & \multicolumn{2}{|r|}{0.005} & & & \\
\hline Breusch-Pagan Test chi2 & \multicolumn{2}{|c|}{$\begin{array}{l}136 \\
0.56\end{array}$} & & & \\
\hline Prob $>$ chi 2 & \multicolumn{2}{|c|}{0.453} & & & \\
\hline Adj. R-squared & \multicolumn{2}{|c|}{0.020} & & & \\
\hline
\end{tabular}

(Note) $* * *, * *$, and $*$ mean $1 \%, 5 \%$, and $10 \%$ statistically significant each other.

\section{Conclusions}

This paper presented an empirical analysis of the factors determining productivity in the software industry in Japan, using individual data from the ' $28^{\text {th }}$ Survey of the State of the Information Service Industry' conducted in August 2006. Software enterprises were classified as prime contractors, intermediate subcontractors, endcontractors, and independent enterprises. There are hierarchical structure among prime contractors, intermediate subcontractors and end-contractors, outsourcing the software development from upstream to downstream. This hierarchical structure of the software industry is considered particularly prominent for custom software which is popular in Japan compared with the U.S., European countries, and India. One of 
the reasons why the share of custom software is higher in Japan than other countries is that IT vendor ${ }^{8}$ has had the dominant power in this strong hierarchical structure.

Comparing productivity revealed that productivity was lowest for intermediate subcontractors. They play as Intermediary to connect prime contractors and endcontractors. The technology level is the highest in prime contractors which introduces new technology. On the other hand, the tacit knowledge ${ }^{9}$ of software development tends to be accumulated in the actual development process which is mainly charged in end-contractors.

The estimation results show that the empowerment of labor quality can have the correlation with the productivity in intermediate subcontractors. ITEE qualifies the ability of system engineer and programmer. IT skill standard defines the skills for IT human resources clearly and systematically. The knowledge of software development is not formalized in intermediate subcontractors compared with prime contractors. So to utilize ITEE or IT skill standard is one of effective method in intermediate subcontractors.

The share of intermediate subcontractors to total enterprises is above $25 \%$. To raise the productivity in intermediate subcontractors can lead to bring higher productivity in the Japanese software industry as a whole.

Our estimation results of this paper can develop the conclusion shown in Minetaki and Motohashi [6], from organization skill towards individual employee's skill. Also our this paper can provide the way how to change the subcontracting structure in the Japanese software industry, on the other hand Nishimura and Minetaki [5] only shows the inefficiency structure in this industry.

In future, the stream where software is considered as a service will spread and change the industrial organization in the Japanese software industry. According to Cusumano [9], the most significant change in software industry is the decline of traditional product sales or license fees and the shift in product company revenues to services. Subcontractor enterprises which have abundant human resources and can adjust to the new stream in the software industry will have the chance to become independent and grow ${ }^{10}$.

${ }^{8}$ Major IT vendors are Hitachi, Fujitsu, and NEC which have produced both main frame computer and custom software in Japan.

${ }^{9}$ Brooks [8] shows that an increase in the number of programmers or system engineers can actually have a negative impact on productivity for software firms, particularly in cases where communication among programmers or system engineers plays a vital role. This implies that the exchange of tacit knowledge among employees is very difficult, and therefore it decreases the productivity consequently.

${ }^{10}$ Cusumano [9] shows that in the case of Siebel, their product sales fell dramatically before it was acquired by Oracle and, Even Oracle experienced the "crisscross" (service and maintenance revenues crossing over to exceed product revenues) as long ago as 1997. "For Oracle or Siebel, either their product sales were dropping or product prices were falling." (Cusumano [9]) On the other hand, Cusumano [9] introduces the company of Salesforce.com for the example of the provider of SaaS (Software as a Service). 


\section{Acknowledgements}

We would like to thank IPA (Information-Technology Promotion Agency, Japan) that permits us to use individual data from the ' $28^{\text {th }}$ Survey of the State of the Information Service Industry' conducted in August 2006. Also we would like to thank to RIETI (Research Institute of Economy, Trade and Industry) to provide us with the opportunity conduct this research. This work is supported in part by Japan Society for the Promotion of Science: Grant-in-Aid for Scientific Research (B) (21330061).

\section{References}

1. Imai, K., Ishino, F.: Software business in Japan. Business Review. 41(1), 1-18, 1991 (in Japanese)

2. Tanaka, T.: Software industry. Goto, A., Odagiri, H.: IT Science-based Industries. NTT publishing Co. Ltd., 253-278, 2003 (in Japanese)

3. Motohashi, K.: The IT revolution's implications for the Japanese economy. Takeuchi, H., Shibata, T.: Japan: Moving Toward a More Advanced Knowledge Economy. World Bank Institute, 89-104, 2006

4. Shintani, M.: Quantitative analysis of the structural change in the Japanese information service industry by using micro data. Japan Society for the Promotion of Science: Grant-inAid for Scientific Research, 1-31, 2002 (in Japanese)

5. Nishimura, G., Minetaki, K.: Information Communication Technology and the Japanese Economy. Yuhikaku, 2004 (in Japanese)

6. Minetaki, K., Motohashi, K.: Subcontracting structure in the software industry - empirical study of innovation and productivity. RIETI Discussion Paper Series. 09-J-002, 1-26, 2009 (in Japanese)

7. Hiromatsu, T., Tsubone, N., Kurita, M., Kobayashi, M.: An empirical study on effects of management resources giving to value added through scale economies in information services industry. Journal of the Japan Society for Management Information. 17(1), 25-49, 2008 (in Japanese)

8. Brooks, F. P. Jr.: The Mythical Man-Month: Essays on Software Engineering Anniversary edition. Addison-Wesley Publishing Company Inc., 1996

9. Cusumano, M.: The changing software business: from products to services and other new business models. The MIT Center for Digital Business Paper. 236, 1-24, 2008 